\title{
Obituary
}

\section{Professor Sir Ronald Nyholm}

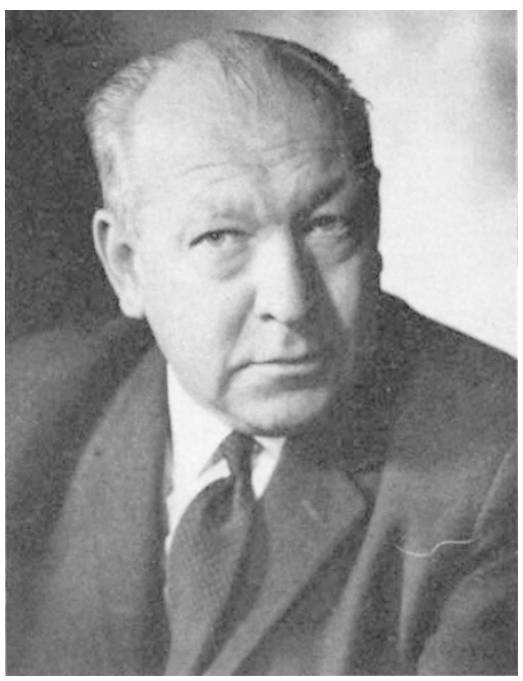

Photo by Godfrey Argent

THE tragic death of Sir Ronald Nyholm in a car accident on December 4, 1971, will come as a sad blow to all who have ever come in contact with him.

Born in 1917, Ronald Nyholm graduated from the University of Sydney, Australia, in 1938, and then joined the staff of Sydney Technical College before moving to England as an ICI Fellow in 1947. Nyholm was one of the immediate post-war group who founded in University College Chemistry Department an active colony of Australian chemistry which persists to this day. At University College he readily interacted with the local attitude to chemistry and found, in particular, rapport with the philosophy of Sir Christopher Ingold who was the head of the department. After returning to Australia in 1952 as an Associate Professor of Chemistry at the University of Technology in Syơney he assumed a chair of chemistry at University College London in 1955, where he became head of the department in 1966 on the death of Professor E. D. Hughes.

Ron Nyholm's impact on inorganic chemistry has been tremendous. He was one of a small band of inorganic chemists who in the immediate post-war years established the present discipline and transposed it from the essential factual approach of the pre-war years to the physico-chemical based discipline of today. In particular his interest in transition metal chemistry, coupled with his fluency in lecturing and presenting an attractive thesis, helped to direct the course of inorganic chemistry in Britain.
The title of his inaugural address at University College, The Renaissance of Inorganic Chemistry, was apt; in this, he developed the theme that was to prove his basic philosophy for the next sixteen years, namely a total integration of chemistry, with physical chemistry providing a tool for the rationalization of inorganic chemistry and with organometallic chemistry as a natural and fruitful bridge between inorganic and organic chemistry.

Nyholm's initial research was concerned with the coordination chemistry of the later transition elements with monodentate arsine ligands, an area very much in the tradition of Australian inorganic chemistry as initiated by G. J. Burrows. Although Nyholm never published a paper with Burrows he often recounted his debt to this worker who in many ways he considered his mentor in this field. Much of the early work was carried out in collaboration with that other great Australian coordination chemist, Frank Dwyer, and it is of interest that together these workers have spread their influence over much of Australian and English inorganic chemistry.

On his arrival at University College, Nyholm took the opportunity to review the factors that influenced the stereochemistry of the group VIII elements ${ }^{1}$ and became interested in the potential use of magnetic measurements in elucidating stereochemical problems for the transition elements. This is a theme that ho proceeded to develop with considerable success for the next twenty years. His application of magnetic measurements to chemical problems was the first of a series of adaptations of physical methods to inorganic chemistry and his interest in the development of instrumentation was an important factor in his work. He had the facility to recognize the potential use of many of the newer physical methods that developed after 1950, and was a prime mover in the adaptation of vibration, electronic and magnetic spectroscopy in the widest possible forms to inorganic problems. Nyholm was nevertheless primarily a synthetic inorganic chemist who always enjoyed preparing a new compound.

The initial preparative work he carried out in London was in the area of polydentate arsine derivatives, and after some work on tertiary arsine complexes, his attention was taken with the di-tertiary arsine, orthophenylenebisdimethylarsine (diarsin), initially discovered by
Chatt and Mann. This ligand provided Nyholm with the degree of versatility he was seeking and for the next twenty years he proceeded to use this as a stabilizing group to uncover larger areas of interesting transition metal chemistry. His paper on the trivalent and tetravalent complexes of nickel ${ }^{2}$ was the first of a series of publications dealing with uncommon oxidation states of transition metal ions stabilized by diarsine. $\mathrm{He}$ further utilized this ligand in establishing the then unusual coordination number, and stereochemical arrangements of three, five, seven and eight groups for a variety of elements and in particular the arrangements of seven and eight coordination for first row transition elements. $\mathrm{He}$ always attempted to establish the presence and arrangements of complexes of this type by appeal to physical methods while rationalizing their stability and structure in terms of thermodynamic and quantum mechanical theory.

One of Nyholm's real contributions was his insight into the generalities of a subject and his publications have been punctuated by a liberal interjection of review articles in which he attempted to summarize an area with particular emphasis on the generalities underlying the subject. Perhaps the most significant of all these was his Tilden lecture of 1960 , in which he reviewed the use of ionization potential-promotion energy data to the understanding of the reactivity and stereochemistry of transition metal complexes and the overall relationship between electron structure and configuration of transition metal complexes ${ }^{3}$. This work provides us with one of the best summaries of the salient factors in the field. This facility for seeing the general, coupled with his lucidity in speech, made him one of the most popular lecturers on both the national and international scene.

Nyholm's researches in transition metal chemistry ranged over all possible areas but were particularly concerned with metal carbonyl, metal-metal bonded systems, unusual stereochemistries and more recently in the reactivity of coordinated organic groups. He was a prime mover in the development of ligand field theory to inorganic complexes and with Ingold and Tobe initiated mechanistic studies in transition metal complexes. There are few fields of transition metal chemistry in which Nyholm did not make a significant contribution. Recently his expertise in co- 
ordination chemistry was extended to the complexes formed by. the alkali metals and alkaline earth elements with a variety of polydentate ligands, under the auspices of the ARC. This work emphasized his view that coordination chemistry was an approach to chemistry rather than a branch of it and brought his interests into the bio-inorganic chemical scene. Nyholm's influence in chemistry will continue for many years not only through his published work but also through his students. All who came in contact with him as a research worker were impressed by his attitudes to his chemistry and certainly many will perpetuate the Nyholm philosophy of the subject.

In addition to his research, Nyholm made his impact on virtually all aspects of chemistry. In teaching he was interested in the problems of the school, the technical college and the University. His chairmanship of the Nuffield Schools chemical project was active and his attempts to influence the course of teaching of chemistry realistic. His efforts to transpose difficult theoretical concepts to an understandable form, at the school level, often posed his colleagues with testing questions in their own discipline which plumbed their own understanding. Thus the utilization of the lone-pair repulsion theory in considering the stereochemistry of inorganic molecules, with R. J. Gillespie, allowed for an inclusion of stereochemical consideration into the ' $O$ ' level chemistry course, adding a third dimension to school chemistry courses. His influence on $\mathrm{ONC}$ and $\mathrm{HNC}$ courses of inorganic chemistry in technical colleges was also profound and his recent development into first year university teaching of chemistry emphasized his progressive attitude to the teaching of the subject. Of the many committees with which Nyholm was associated, his educational interests were of considerable importance to him, both on the national and international level.

His contributions in the areas of industry and government committees were also significant. In particular his active participation in the SRC, both on general committees and as chairman of the chemical committee, allowed his liberal and realistic views to be felt. $\mathrm{He}$ was a prime mover in the recent merger of the various Chemical Societies, and during his tenure of the office of President of the Chemical Society he actively pursued the policy to a successful conclusion.

Rightly during his chemical career, Nyholm received many accolades including several honorary degrees and numerous other awards. He was elected a Fellow of the Royal Society in 1958, and was knighted in $1967 . \mathrm{He}$ was President of the Chemical Society from 1968 to 1970 and President of the Association for Science Education in 1967.

Ron Nyholm's influence on inorganic chemistry has been deep and he will be sadly missed as a chemist; but many people will miss him primarily as a friend. The students, friends and scientists who have shared in the hospitality of his household will recognize that he was principally a family man, and will wish to extend their sympathy to his family at this time.

\footnotetext{
1 Quart. Rev., 3, 321 (1949).

2 Nature, 165, 154 (1950).

3 Proc. Chem. Soc., 273 (1961).
}

\section{Announcements}

\section{Appointments}

Professor B. C. L. Weedon has been reappointed chairman of the Food Additives and Contaminants Committee; Professor F. Aylward, Dr J. H. Hamence, Mr J. Saunders and Professor E. F. Williams have been reappointed to the committee, and Dr W. C. Fulton and Professor M. Ingram have been appointed as additional members.

\section{Miscellaneous}

The sixth Stephen Rothman award of the Society for Investigative Dermatology Inc. will be presented to Dr William Montagna, director of the Oregon Regional Primate Center.

The Steacie prize for 1971 has been awarded to Professor G. A. Gratzer, University of Manitoba. The award is made annually in commemoration of Dr E. W. R. Steacie, president of the National Research Council of Canada during 1951-62, and consists of a cash award of $\$ 1,500$.

The Lomonosov gold medals for 1971the highest annual award of the Soviet Academy of Sciences, traditionally awarded to one Soviet and one foreign scientist each year--have been awarded to Academician Viktor Amazaspovich Ambartsumyan of the Armenian SSR for his outstanding achievements in astronomy and astrophysics, and to Professor Hannes Alfvén of Sweden for "outstanding achievements in the field of plasma physics and astrophysics".
(Continued from $p .140$ )

19 LoGerfo, P., Krupey, J., and Hansen, H. J., New Engl. J. Med., 285, 138 (1971)

20 Gold, P., Gold, J. M., and Freedman, S. O., Cancer Res., 28 , 1331 (1968).

21 Thomson, D. M. P., Krupey, J., Freedman, S. O., and Gold, P., Proc. US Nat. Acad. Sci., 64, 161 (1969).

22 Moore, T. L., Kupchik, H. Z., Marcon, N., and Zamcheck, N., Amer. J. Digestive Diseases, 16, 1 (1971).

23 Collatz, E., Kleist, Svon, and Burtin, P., Int. J. Cancer, 8, 298 (1971).

${ }^{24}$ Hollinshead, A., Glew, D., Bunnag, B., Gold, P., and Herberman, R. Lancet, i, 1191 (1970); Lejtenyi, M. C., Freedman, S. O. and Gold, P., Cancer, 28, 115 (1971).

${ }^{25}$ Hakkinen, I., Scand. J. Gastroenterology, 1, 28 (1966); Ann. Surgery, 169, 277 (1969).

26 Nairn, R. C., Fothergill, J. E., McEntegart, M. G., and Porteous, I. B., Brit. Med. J., 1, 1788 (1962).

27 de Boer, W. R. G. M., Forsyth, A., and Nairn, R. C., Brit. Med. J., 3, 93 (1969).

28 Fishman, W. H., et al., Nature, 219, 697 (1968)

29 Stolbach, L. L., Krant, M. J., and Fishman, W. H., New Engl, J. Med., 281, 757 (1969)

30 Edynak, E. M., Old, L. J., Vrana, M., and Lardis, M., Proc. Amer Assoc. Cancer Res., 11, 22 (1970).

31 Stonehill, E. H., and Bendick, A., Nature, 228, 370 (1970).

32 Huebner, R. J., et al., Proc. US Nat. Acad. Sci., 67, 366 (1970).

33 Wang M., Int J. Cancer, 3, 483 (1968).

34 Alexander, P., Proc. Conf. on Embryonal and Foetal Antigens (Knoxville, in the press, 1971).

35 Pearson, G., and Freeman, G., Cancer Res., 28, 1665 (1968).
36 Duff, R., and Rapp, F., J. Immun., 105, 521 (1970).

37 Coggin, J. H., Ambrose, K. R., and Anderson, N. G., J. Immun., $105,524(1970)$

38 Koprowski, H., Sawicki, W., and Koldovsky, P., J. Nat. Cancer Inst., 46, 1317 (1971).

39 Moscona, A. A., Science, 171, 905 (1971).

40 Burger, M. M., and Goldberg, A. R., Proc. US Nat. Acad. Sci., 57, 359 (1967).

41 Inbar, M., and Sachs, L., Nature, 223, 710 (1969).

42 Cline, M. J., and Livingston, D. C., Nature New Biology, 232. 155 (1971).

43 Ozanne, B., and Sambrook, J., Nature New Biology, 232, 156 (1971).

44 Cumar, F. A., Brady, R. O., Kolodny, E. H., McFarland, V. W., and Mora, P. T., Proc. US Nat. Acad. Sci., 67, 757 (1970).

45 Burger, M. M., Nature New Biology, 231, 1251 (1971).

46 Fox, T. O. Sheppard, J. R., and Burger, M. M., Proc. US Nat. Acad. Sci. 68, 244 (1971).

47 Ting, R., Nature, 217, 858 (1968)

48 Blair, P. B., Cancer Res., 30, 1199 (1970)

49 Banna, M. G. Tennant, W., and Coggin, J. H., Proc. US Nat. Acad. Sci., 68, 1748 (1971).

50 Buttle, G. A., Eperon, J. L., and Kovaks, E., Nature, 194, 780 (1962).

51 Buttle, G., and Frayn, A., Nature, 215, 1495 (1967).

52 Fibiger, J., Acta Pathol. Microbiol. Scand., 4 (Issue 2) (1927).

53 Coggin, J. H., et al., Nature, 233, 194 (1971).

54 Prehn R. T in Cross-reacting Antigens and Neoantigens (edit. by Trentin, J. J.), 105 (Williams and Wilkins, Baltimore, 1967).

55 Old, L. J., Boyse, E. A., and Stockert, E., J. Nat. Cancer Inst., 31 977 (1963). 